carried out the duties of local secretary, and Mr. Spooner, who acted as leader in the field.

Members had the choice of one of three excursions on the afternoon of June $2:$ a visit to the Aquarium and Laboratory of the Marine Biological Association; Ruckland Abbey; and Plympton Castle.

\section{SOVIET FAMILY LEGISLATION}

CONSIDERING the concept of the family in $\checkmark$ Soviet life Dr. R. A. J. Schlesinger suggests that the U.S.S.R. does not just represent an attempt at the application of socialist theories in a modern industrial society. In considering any matter in the U.S.S.R. it should be realized that it is not a country but a continent; at the time of the Bolshevik revolution Russia comprised a greater variety of civilizations than it does at present, after a systematic process of industrialization (Health Educ. J., 10, No. 2 ; April 1952).

In some areas until quite recently millions of peasant homes in Russia were man-dominated in the most brutal sense of the term, and women's condition deteriorated, at least in the poor peasant's home when the economic differentiation in the village increased its dependence on the richer neighbour. Of the Islamic regions some- especially the Volga Tartarswere fairly advanced; but most of them (especially Central Asia) belonged to the most backward provinces of the Islamic world. There were large areas over which a primitive tribal organization was still in operation. As late as 1936 the Government struggle against blood-feud was just in its concluding stage. Large sections of the penal codes of the Republics concerned dealt with paying bride-price, abducting women, polygamy, marriage of minors and similar "offences originating from tribal custom", some of which (for example, marriage of minors) came under heavy penal sanctions only if they were caused by local custom which the legislator wished to repress in the interest of the emancipation of women.

Confronted with the initiation of a revolution in human relations against the prejudices of primitive custom, the Soviet state has firmly kept to the Marxist concept that undesirable phenomena in family life should, and can, be overcome by the removal of their economic causes. In 1935 Stalin hailed the Labour Day as the great emancipator of peasant women because it granted them an income independent of that of their menfolk. To-day the Soviet Government is attempting to construct a modern industrial society in which its policies aim at stabilizing family relationships in such a society.

Before this were possible, however, certain 'housecleaning' had to be concluded. In the 'house-cleaning' programme the first enactments of the revolutionary Government did not exceed measures current in modern legislation elsewhere. They were revolutionary only in comparison with 'Tsarist Russian legislation and consisted of such measures as the transfer of marriage and divorce from the Church to the registrar's office, admission of divorce on the joint petition of both parties, or by court decision on the petition of only one party, the decision being left to the judge's discretion.

Much confusion about the real social situation has been created and is still being created by exaggerated emphasis on some literary pronouncements. Even in statements by authors who must be regarded as characteristic of the Soviet outlook, concepts of an eventual withering away of the family played a predominant part. The withering process, however, always referred to the family as an economic unit of consumption and as the main place of education, and not as a normally permanent union of man and wife. To some extent this may have been due to the impact of the more Utopian elements of Marxist ideology, to some extent to exaggerated estimates of the potentialities of some measures which are clearly necessary in order to enable women to take their share in production, such as creches, pre-school education and public canteens.

This view has now completely changed and, in all Soviet publications since 1936, the family is described with great fervour as "the primary unit of our Soviet society". The Ministry of Education publishes a special monthly, Family and School, to promote collaboration between home and school and the activities of parents' committees. Great emphasis is laid upon the responsibilities, not only of parents towards their children, but also of the younger members of the family towards the aged ones. The reasons for this change are political as well as economic.

After having passed its revolutionary period-. which, a posteriori, is explained by the consideration - that it was necessary in order to break up some millions of unfree relationships and to establish the principle of equality of the sexes-Soviet legislation, as enacted in the period 1936-45, has come to conclusions very similar to those current in other advanced industrial countries. Most of the differences may be explained by the absence of traditional prejudice; the Soviet State can leave the decision upon whether a divorce should be granted or not to the judge's common sense, without binding him by enumerating grounds for divorce, the presence of which gives a claim to, and the absence of which excludes, granting of a divorce. It can also encourage marriage without paying tribute to the concept that being an unmarried mother is morally wrong.

In essence, however, the conclusions arrived at are the same: marriage is the normal way to motherhood; the family home is the ordinary, though not the only, place to rear the new generation; men and women have equal rights within the family as well as in professional life. The real problems of the Soviet approach to the family arise less from the consummation of the permanent results of the feminist movement than from the potential contradiction between the recognition of the family home as one centre in the education of the future citizen and the demand for the access of women, not only in theory, but also in practice, to all professions for which they are physically fitted.

\section{INHIBITION OF CESTRUS BY CULTIVATED GROMWELL}

By DR. B. P. WIESNER and PROF. JOHN YUDKIN Department of Physiology, King's College of Househo'd and Social Science (University of London)

$\mathrm{N}$ one settlement of the Shoshone Indians, infusions of the roots of Lithospermum ruderale, Dougl. taken orally, were believed to have contraceptive properties. ${ }^{1}$ Prompted by this, Cranston ${ }^{2}$ administered fluid extracts of the herb to mice in their food. She observed inhibition of cestrus and fertility during treatment, without any evidence of general toxicity. 